\title{
REPRESENTASI DALAM PEMBELAJARAN MATEMATIKA
}

\author{
Muhamad Sabirin
}

\begin{abstract}
Abstrak
Representasi adalah bentuk interpretasi pemikiran siswa terhadap suatu masalah, yang digunakan sebagai alat bantu untuk menemukan solusi dari masalah tersebut. Bentuk interpretasi siswa dapat berupa kata-kata atau verbal, tulisan, gambar, tabel, grafik, benda konkrit, simbol matematika dan lain-lain. Makalah ini membahas tentang representasi matematis dan contoh penggunaannya dalam pembelajaran matematika.
\end{abstract}

Kata Kunci: Representasi Matematis,Pemecahan Masalah,Soal non-Rutin.

\section{Pendahuluan}

Kemampuan representasi matematis merupakan salah satu tujuan umum dari pembelajaran matematika di sekolah. Kemampuan ini sangat penting bagi siswa dan erat kaitannya dengan kemampuan komunikasi dan pemecahan masalah. Untuk dapat mengkomunikasikan sesuatu, seseorang perlu representasi baik berupa gambar, grafik, diagram, maupun bentuk representasi lainnya. Dengan representasi, masalah yang semula terlihat sulit dan rumit dapat di lihat dengan lebih mudah dan sederhana, sehingga masalah yang disajikan dapat dipecahkan dengan lebih mudah.

Makalah ini membahas tentang pengertian dan jenis representasi dan bagaimana representasi digunakan dalam pembelajaran matematika.

\section{A. Kemampuan Representasi Matematis}

Representasi adalah model atau bentuk pengganti dari suatu situasi masalah yang digunakan untuk menemukan solusi. Sebagai contoh, suatu masalah dapat direpresentasikan dengan obyek, gambar, kata-kata, atau simbol matematika (Jones \& Knuth, 1991). Dalam NCTM (2000) 
dinyatakan bahwa representasi merupakan cara yang digunakan seseorang untuk mengkomunikasikan jawaban atau gagasan matematik yang bersangkutan.

Representasi yang dimunculkan oleh siswa merupakan ungkapanungkapan dari gagasan-gagasan atau ide-ide matematika yang ditampilkan siswa dalam upayanya untuk mencari suatu solusi dari masalah yang sedang dihadapinya (NCTM, 2000: 67).

Menurut Pape \& Tchoshanov (dalam Luitel, 2001) ada empat gagasan yang digunakan dalam memahami konsep representasi, yaitu: (1) representasi dapat dipandang sebagai abstraksi internal dari ide-ide matematika atau skemata kognitif yang dibangun oleh siswa melalui pengalaman; (2) sebagai reproduksi mental dari keadaan mental yang sebelumnya; (3) sebagai sajian secara struktur melalui gambar, simbol ataupun lambang; (4) sebagai pengetahuan tentang sesuatu yang mewakili sesuatu yang lain.

Representasi merupakan proses pengembangan mental yang sudah dimiliki seseorang, yang terungkap dan divisualisasikan dalam berbagai model matematika, yakni: verbal, gambar, benda konkret, tabel, modelmodel manipulatif atau kombinasi dari semuanya (Steffe, Weigel, Schultz, Waters, Joijner, \& Reijs dalam Hudoyo, 2002: 47). Cai, Lane, dan Jacabcsin (1996: 243) menyatakan bahwa ragam representasi yang sering digunakan dalam mengkomunikasikan matematika antara lain: tabel, gambar, grafik, pernyataan matematika, teks tertulis, ataupun kombinasi semuanya.

Hiebert dan Carpenter (dalam Hudoyo, 2002) mengemukakan bahwa pada dasarnya representasi dapat dibedakan dalam dua bentuk, yakni representasi internal dan representasi eksternal. Berpikir tentang ide matematika yang kemudian dikomunikasikan memerlukan representasi eksternal yang wujudnya antara lain: verbal, gambar dan benda konkrit. Berpikir tentang ide matematika yang memungkinkan pikiran seseorang bekerja atas dasar ide tersebut merupakan representasi internal. 
Representasi dalam Pembelajaran Matematika

Lesh, Post dan Behr (dalam Hwang, Chen, Dung, \& Yang, 2007) membagi representasi yang digunakan dalam pendidikan matematika dalam lima jenis, meliputi representasi objek dunia nyata, representasi konkret, representasi simbol aritmetika, representasi bahasa lisan atau verbal dan representasi gambar atau grafik.

Dari uraian di atas dapat disimpulkan bahwa representasi adalah bentuk interpretasi pemikiran siswa terhadap suatu masalah, yang digunakan sebagai alat bantu untuk menemukan solusi dari masalah tersebut. Bentuk interpretasi siswa dapat berupa kata-kata atau verbal, tulisan, gambar, tabel, grafik, benda konkrit, simbol matematika dan lainlain.

\section{B. Representasi Matematis dalam Pembelajaran Matematika}

Representasi sangat berperan dalam upaya mengembangkan dan mengoptimalkan kemampuan matematika siswa. NCTM dalam Principle and Standars for School Mathematics (Standars, 2000) mencantumkan representasi (representation) sebagai standar proses kelima setelah problem solving, reasoning, communication, and connection. Menurut Jones (2000) beberapa alasan penting yang mendasarinya adalah sebagai berikut:

1. Kelancaran dalam melakukan translasi di antara berbagai bentuk representasi berbeda, merupakan kemampuan mendasar yang perlu dimiliki siswa untuk membangun konsep dan berpikir matematis.

2. Cara guru dalam meyajikan ide-ide matematika melalui berbagai representasi akan memberikan pengaruh yang sangat besar terhadap pemahaman siswa dalam mempelajari matematika.

3. Siswa membutuhkan latihan dalam membangun representasinya sendiri sehingga memiliki kemampuan dan pemahaman konsep yang kuat dan fleksibel yang dapat digunakan dalam memecahkan masalah.

Meskipun demikian, ada beberapa keberatan dari para ahli matematika yang berkaitan dengan dimasukkannya representasi sebagai standar proses seperti yang diungkapkan Jones (2000) sebagai berikut: 
1. Anggapan bahwa representasi adalah sinonim dengan model matematika. Ini berarti bahwa representasi sudah merupakan bagian dari standar isi, khususnya dalam aljabar yang berkaitan dengan rumusrumus dan fungsi yang dideskripsikan sebagai standar bahwa "siswa dapat menggunakan model-model matematika dan menganalisis perubahan dalam konteks real dan abstrak."

2. Representasi adalah hanya bagian dari proses pemecahan masalah dan hal ini sudah tercakup dalam standar pemecahan masalah. Selain itu, kelebihan dari representasi sebagai standar proses tidak begitu penting. Standar proses dari pemecahan masalah, komunikasi, penalaran dan koneksi semua memuat standar isi yang tidak dibatasi dalam representasinya

3. Representasi sebagai bagian dari perkembangan kognitif tidak memberikan jaminan memiliki peranan yang menonjol dalam sajianmasalah matematika.

Menanggapi keberatan di atas, beberapa ahli pendidikan matematika dan peneliti aliran kognitif menyatakan bahwa representasi tidak hanya membahas terbatas pada penggunaan notasi simbol untuk menterjemahkan suatu situasi ke langkah matematika. Representasi lebih dari sekedar produk fisik hasil observasi. Representasi juga merupakan proses kognitif yang terjadi secara internal. Representasi adalah suatu aktivitas interpretasi konsep atau masalah dengan memberikan makna (Hudiono, 2007). Dalam pembelajaran, melalui representasi eksternal siswa, guru dapat menebak apa yang sesungguhnya terjadi yang merupakan representasi internal dalam benak siswa, sehingga guru dapat melakukan langkah yang tepat untuk membawa siswa belajar.

Sebagai salah satu standar proses maka NCTM (2000) menetapkan standar representasi yang diharapkan dapat dikuasai siswa selama pembelajaran di sekolah yaitu:

1. membuat dan menggunakan representasi untuk mengenal, mencatat atau merekam, dan mengkomunikasikan ide-ide matematika; 
Representasi dalam Pembelajaran Matematika

2. memilih, menerapkan, dan melakukan translasi antar representasi matematis untuk memecahkan masalah;

3. menggunakan representasi untuk memodelkan dan menginterpretasikan fenomena fisik, sosial, dan fenomena matematika.

Ketika siswa dihadapkan pada suatu situasi masalah matematika dalam pembelajaran di kelas, mereka akan berusaha memahami masalah tersebut dan menyelesaikannya dengan cara-cara yang mereka ketahui. Cara-cara tersebut sangat terkait dengan pengetahuan sebelumnya yang sudah ada yang berhubungan dengan masalah yang disajikan. Salah satu bagian dari upaya yang dapat dilakukan siswa adalah dengan membuat model atau representasi dari masalah tersebut. Model atau representasi yang di buat bisa bermacam-macam tergantung pada kemampuan masingmasing individu dalam menginterpretasikan masalah yang ada.

Pembelajaran matematika di kelas hendaknya memberikan kesempatan yang cukup bagi siswa untuk dapat melatih dan mengembangkan kemampuan representasi matematis sebagai bagian yang penting dalam pemecahan masalah. Masalah yang disajikan disesuaikan dengan isi dan kedalaman materi pada jenjang masing-masing dengan memperhatikan pengetahuan awal atau prasyarat yang dimiliki siswa.

Salah satu contoh masalah matematika dalam NCTM (2000) yang terkait dengan representasi matematis disajikan dalam contoh berikut:

"Apa yang akan terjadi terhadap luas daerah sebuah persegi panjang jika panjang sisinya menjadi dua kali panjang semula?"

Masalah di atas menarik untuk disajikan karena siswa ditantang untuk berpikir menggunakan informasi yang tersedia dan mengaitkannya dengan pengetahuan yang sudah mereka miliki sebelumnya. Masalah tersebut juga memungkinkan untuk diselesaikan dengan lebih dari satu cara.

Salah satu contoh pemecahan masalah yang mungkin dilakukan siswa adalah dengan menyelesaikannya secara langsung yakni menggunakan representasi simbolik sebagai berikut: 
“Misalkan persegi panjang semula panjangnya $a$ dan lebarnya $b$, sehingga diperoleh luasnya adalah

$$
\mathrm{L}=a \times b=a b .
$$

Jika panjang sisinya menjadi dua kali panjang semula, maka panjangnya $2 a$ dan lebarnya $2 b$, sehingga luasnya menjadi

$$
\mathrm{L}=2 a \times 2 b=4 a b
$$

Jadi dapat disimpulkan bahwa luas persegi panjang yang baru menjadi 4 kali luas persegi panjang semula."

Selain cara tersebut, sebagian siswa mungkin ada yang berfikir tergesa-gesa dan langsung menjawab bahwa luasnya menjadi dua kali dari luas persegi panjang semula. Mereka menduga atau berargumen bahwa jika panjang sisinya dua kali panjang semula tentu luasnya juga akan menjadi dua kali luas persegi panjang semula. Guru harus berusaha memberikan pemahaman yang lebih mudah dipahami agar pemikiran siswa tidak berhenti sampai disitu, misalnya dengan menanyakan kembali jawaban mereka atau meminta untuk berfikir kembali menggunakan cara lain.

Masalah di atas akan lebih mudah di pahami jika disajikan dengan menggunakan representasi gambar sebagai berikut:

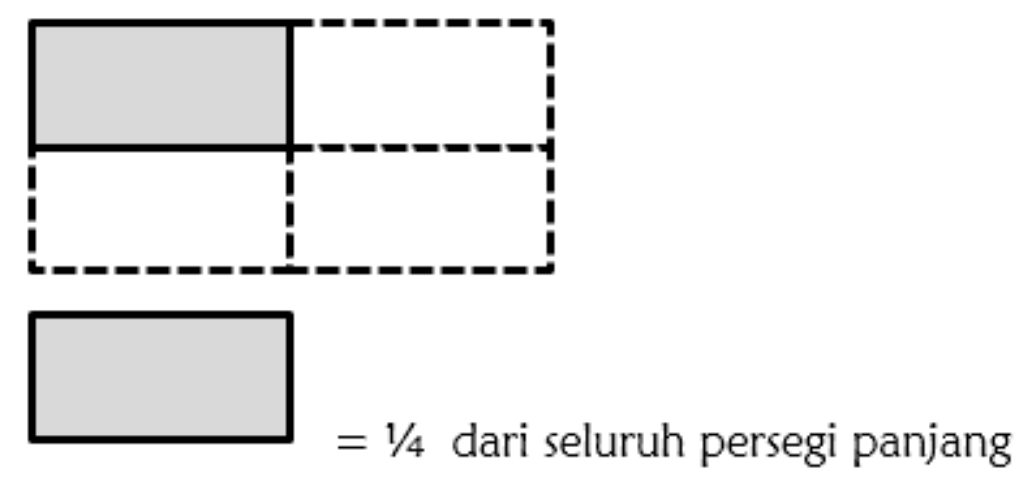

Gambar 1.Representasi siswa sebagai hasil dari menduakalikan ukuran panjang sisi-sisi persegi panjang (NCTM, 2000) 
Representasi dalam Pembelajaran Matematika

Dari hasil representasi gambar 1 sebelumnya, terlihat bahwa penyelesaian dari masalah yang diberikan dapat lebih mudah ditemukan dan dapat menunjukkan dengan jelas bahwa persegi panjang yang baru besarnya empat kali ukuran semula. Aktivitas yang terjadi dalam pembelajaran tidak hanya menunjukkan bagaimana cara siswa menjawab tetapi juga ada proses pembenaran terhadap jawaban siswa yang lain.

Contoh berikut ini di adaptasi dari Bain \& Engelhardts (1992), adalah masalah yang terkait dengan representasi matematis di level perguruan tinggi.

Sebuah tas berisi 3 koin (mata uang logam), 1 koin punya sisi yg sama (keduanya Gambar) dan 2 koin normal. Sebuah koin dipilih secara acak dari dalam tas dan di toss $3 x$. Berapa peluang mendapatkan ketiganya Gambar?

Permasalahan di atas cukup menantang untuk disajikan karena menuntut kemampuan mahasiswa memahami soal dengan baik. Soal ini tergolong jenis soal non rutin. Soal non rutin adalah soal yang membutuhkan penerapan keterampilan pada situasi yang tidak biasa (unfamiliar); perlu mengembangkan strategi untuk masalah yang baru. Soal non rutin juga membutuhkan ekstensi (perluasan) keterampilan atau teori yang sudah dikenal sebelum diterapkan pada situasi yang tidak biasa. Berikut ini salah satu respon mahasiswa terhadap soal di atas:

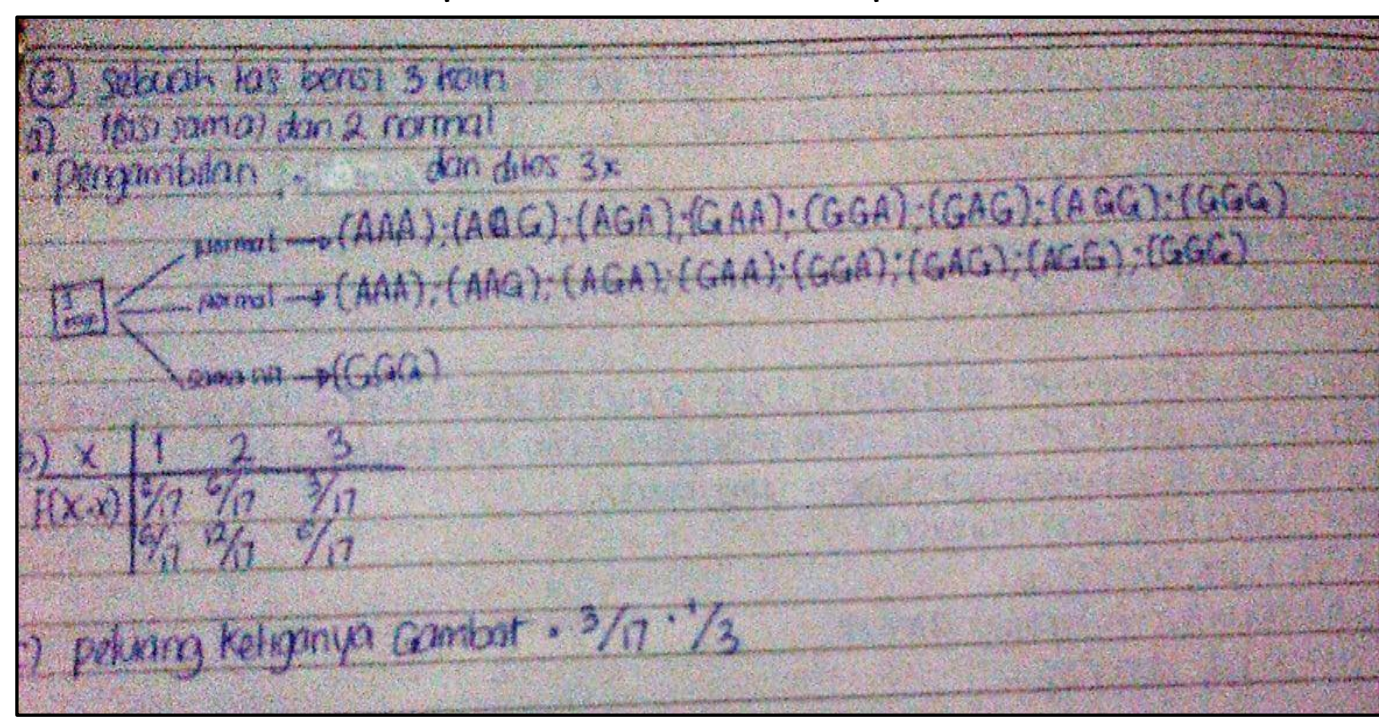

Gambar 2. Representasi mahasiswa dalam menentukan nilai peluang suatu kejadian (Sabirin, 2013) 
Jawaban yang dikemukakan pada gambar 2 memiliki kesalahan yang mendasar dalam menentukan ruang sampel dari masalah yang diberikan. Mahasiswa mengalami kesulitan ketika masalah yang biasa (familiar) diubah settingnya menjadi masalah yang tidak biasa (unfamiliar), yakni koin yang normal (punya dua sisi yang berbeda) diganti menjadi koin yang tidak normal yaitu koin mempunyai dua sisi yang sama (keduanya Gambar). Sehingga banyaknya anggota ruang sampel dari koin yang di toss $3 \times$ menurut mereka sebanyak 17 buah, yang berasal dari koin normal (AAA, AAG, AGA, GAA, AGG, GAG, GGA, GGG) sebanyak 16 buah (2x8) dan dari koin yang bersisi sama (GGG) sebanyak 1 buah. Mereka menghitung bahwa banyaknya GGG sebanyak 3 buah, dan peluangnya adalah 3/17. Kemudian menyimpulkan bahwa peluang mendapatkan ketiganya Gambar (GGG) adalah $3 / 17 \times 1 / 3$, dimana bilangan $1 / 3$ adalah peluang dari masingmasing koin.

Sebenarnya masalah tersebut bisa dipandang sebagai permasalahan biasa sebagaimana koin normal, sehingga banyaknya anggota ruang sampel tetap sebanyak $3 \times 2^{3}=24$ buah. Untuk koin yang bersisi sama (keduanya G), maka banyaknya anggota ruang sampel tetap sebanyak $2^{3}=8$, hanya saja semua anggota ruang sampelnya adalah GCG. Representasi yang dapat digunakan untuk menyelesaikan masalah tersebut misalnya sebagai berikut:

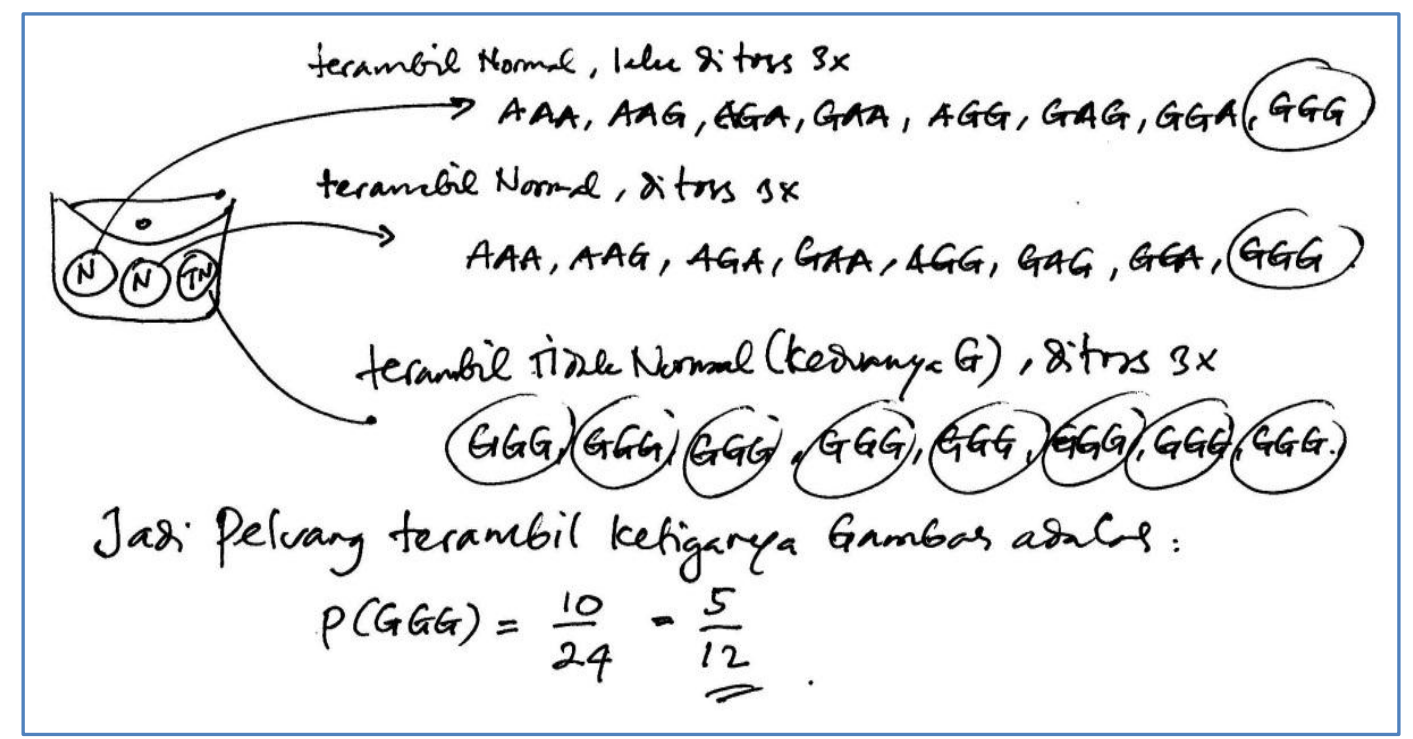

Gambar 3.Representasi dalam menentukan nilai peluang suatu kejadian 
Representasi dalam Pembelajaran Matematika

Representasi yang ditunjukkan pada gambar 3 memandang kejadian secara umum, berdasarkan konsep penentuan ruang sampel dari suatu kejadian. Masing-masing koin yang diasumsikan terpilih kemudian di toss dibuatkan daftar ruang sampelnya. Ruang sampel dari masing-masing koin kemudian digabungkan. Penentuan nilai peluang ketiganya Gambar (GGG) berdasarkan pada ruang sampel secara keseluruhan.

Bentuk representasi yang berbeda dari permasalahan di atas misalnya sebagai berikut:

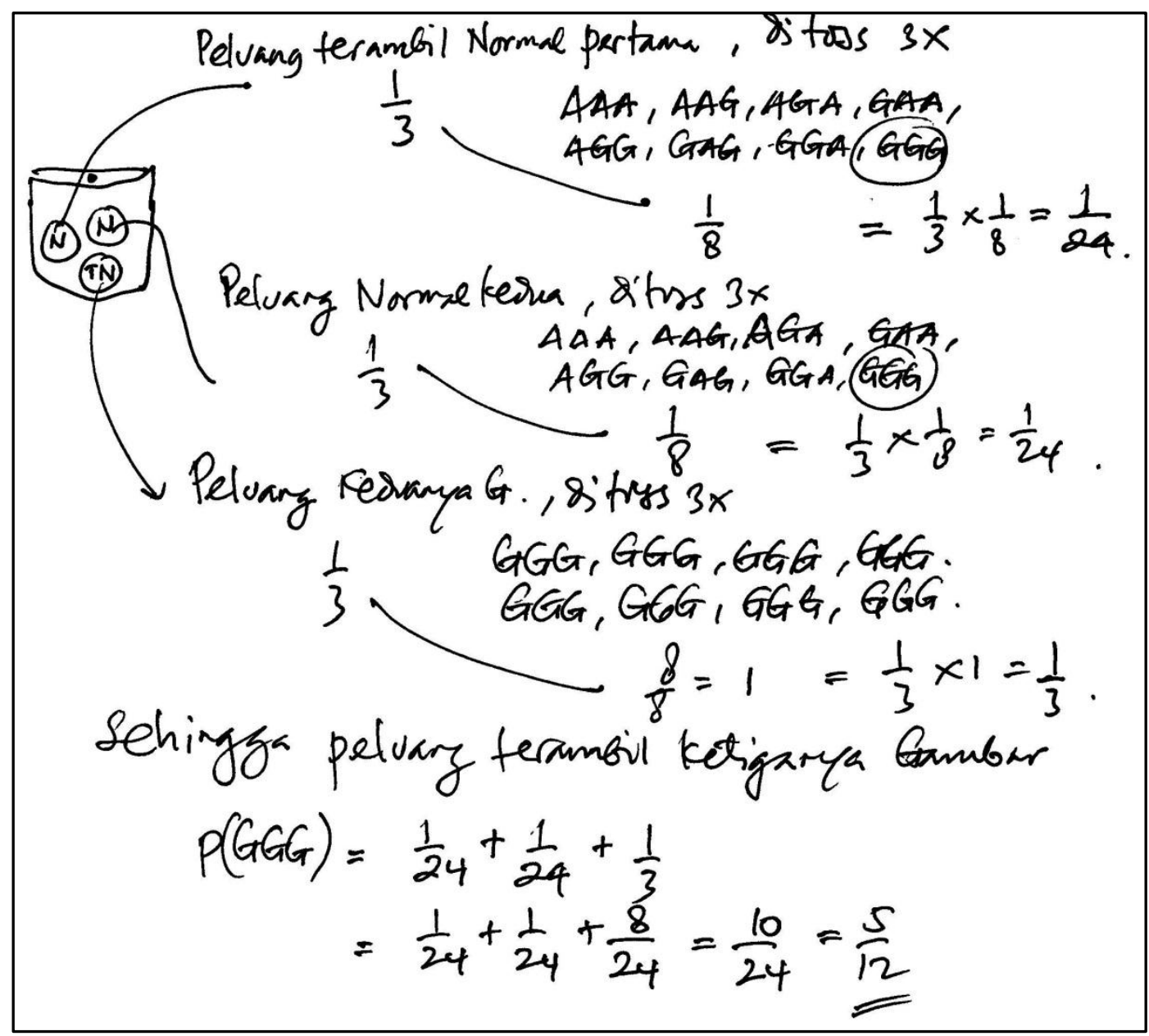

Gambar 4.Representasi dalam menentukan nilai peluang suatu kejadian

Representasi di atas menggunakan konsep peluang total dari suatu kejadian (Law of Total Probability). Peluang masing-masing koin dihitung kemudian dikalikan dengan peluang munculnya (GGG) dengan syarat koin 
terpilih pada masing-masing koin. Peluang Total ketiganya Gambar (GCG) adalah penjumlahan dari peluang (GGG) pada masing-masing koin.

Bentuk representasi yang lebih sederhana dari representasi yang diberikan pada gambar 4 sebelumnya adalah sebagai berikut:

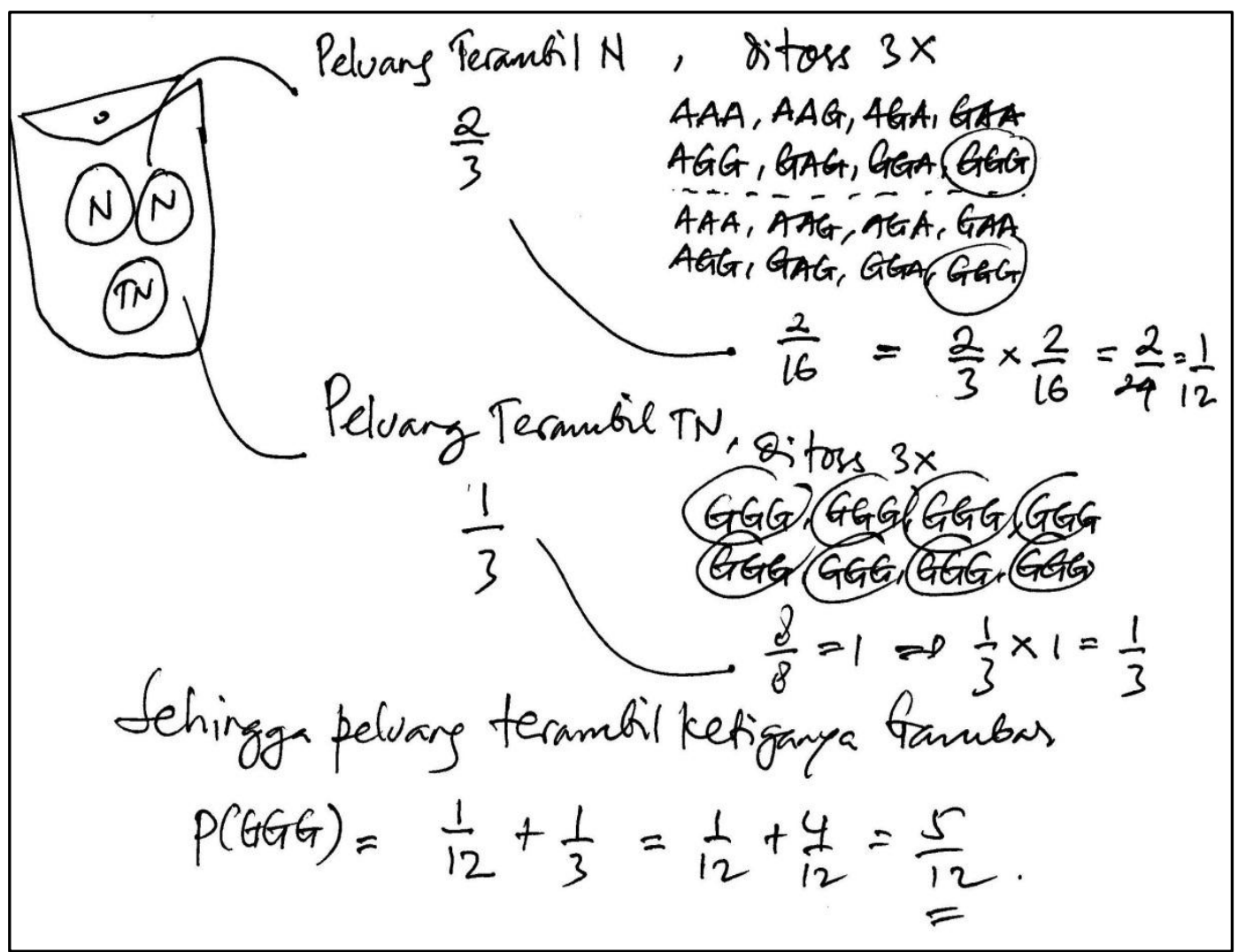

Gambar 5. Representasi dalam menentukan nilai peluang suatu kejadian

Representasi pada gambar 5 juga menggunakan konsep peluang total dari suatu kejadian (Law of Total Probability). Koin dibedakan menjadi dua jenis, yakni Normal (Kedua Sisi Berbeda) danTidak Normal (Kedua sisi sama, keduanya Gambar). Peluang masing-masing jenis koin dihitung, kemudian dikalikan dengan peluang munculnya (GCG) dengan syarat jenis koin terpilih pada masing-masing kejadian. Peluang Total ketiganya Gambar (GGG) adalah penjumlahan dari peluang (GGG) pada masing-masing jenis koin. 
Representasi dalam Pembelajaran Matematika

\section{Kesimpulan}

Kemampuan representasi matematis adalah salah satu kemampuan yang sangat penting bagi siswa dan merupakan salah satu tujuan yang hendak dicapai dalam pembelajaran matematika di sekolah. Representasi sangat berguna dalam membantu siswa menyelesaikan sebuah masalah dengan lebih mudah. Representasi juga berguna sebagai sarana mengkomunikasikan gagasan atau ide matematik siswa kepada siswa lain maupun kepada guru. Pembelajaran matematika di kelas sebaiknya memberikan kesempatan yang cukup bagi siswa untuk melatih dan mengembangkan kemampuan representasi matematis.

\section{Daftar Pustaka}

Bain, J. Lee \& Englehardt, M. Introduction to Probability and Mathematical Statistics. Second Edition. New York: Duxbury Press.

Cai, Lane, Jacabcsin (1996). “Assesing Students' mathematical communication". Official Journal of Science and Mathematics. 96(5).

Hudiono, B (2007). Representasi dalam Pembelajaran Matematika. Pontianak: STAIN Pontianak Press.

Hudoyo, H (2002). Representasi Belajar Berbasis Masalah. Jurnal Matematika dan Pembelajarannya. ISSN: 085-7792. Volume viii, edisi khusus.

Hwang, W.-Y., Chen, N.-S., Dung, J.-J., \& Yang, Y.-L. (2007). Multiple Representation Skills and Creativity Effects on Mathematical Problem Solving using a Multimedia Whiteboard System. Educational Technology \& Society, Vol 10 No 2, pp. 191-212.

Jones, A.D. (2000) The fifth process standard: An argument to include representation in standar 2000. [on-line]. Available: http://www.math.umd.edu/ dac/650/jonespaper.html.

Jones, B.F., \& Knuth, R.A. (1991). What does research ay about mathematics? [on-line]. Available: http://www. ncrl.org/sdrs/areas/stw_esys/2math.html. 
Luitel, B.C. (2001). Multiple Representations of Mathematical Learning. [online]. Available: http://www. matedu.cinvestav.mx/adalira.pdf

NCTM. (1989). Curriculum and Evaluation Standards for School Mathematics. Reston, VA: NCTM.

NCTM. (2000). Principles and Standards for School Mathematics. Reston, VA: NCTM.

Sabirin, M. (2013). Student Performance In Non-Routine Problem Solving On Topic Random Variable And Probability Distribution. Prosiding Konferensi Nasional Pendidikan Matematika V. Malang: UM Press.

\section{Muhamad Sabirin}

IAIN Antasari, Banjarmasin

E-mail: m.sbrn@yahoo.co.id 